\title{
Neurone-specific enolase and S-100: new markers for delineating the innervation of the respiratory tract in man and other mammals
}

\author{
MN SHEPPARD, SS KURIAN, SC HENZEN-LOGMANS, F MICHETTI, D COCCHIA, \\ P COLE, RA RUSH, PJ MARANGOS, SR BLOOM, JM POLAK
}

From the Departments of Histochemistry and Medicine, Royal Postgraduate Medical School, Hammersmith Hospital, London; the Department of Anatomy, Universita Cattolica, Rome; the Cardiothoracic Institute, Brompton Hospital, London; the School of Medicine, Flinders University of South Australia; and the National Institute of Mental Health, Bethesda, Maryland, USA

ABSTRACT Lung innervation has been studied in the past by methylene blue staining and silver impregnation and more recently by histochemical methods. These techniques give only a partial picture of the total innervation. We have delineated the innervation of the lung in man and three other mammalian species by immunostaining with antibodies to two new markers of nervous tissue. These markers are neurone-specific enolase (NSE), an enzyme present in nerve cells in both the central and the peripheral nervous systems, and S-100, a protein found in glial cells. Throughout the respiratory tract NSE was localised in ganglion cells and nerve fibres in all species examined, while S-100 was found in the supporting glial cells of ganglia and in the Schwann cells of peripheral nerves. The distribution of NSE immunoreactivity in serial sections was compared with that of acetylcholinesterase-containing, noradrenergic, and peptide-containing nerves. In all areas NSE was found to be a specific marker for all three types of nerves. Thus these two antibodies provide an effective histological means of examining both the neuronal and the nonneuronal components of the lung innervation and should be of value in investigating this system in lung disease.

The lung has a rich nerve supply, consisting of both sensory and motor divisions. The methods used to demonstrate this innervation by light microscopy in earlier studies included methylene blue and silver staining. ${ }^{1-3}$ More recently, histochemical techniques have been applied, for example, to localise acetylcholinesterase, which is thought to be a marker for cholinergic nerves, ${ }^{4-6}$ and to demonstrate formaldehyde-induced fluorescence in aminergic nerves. ${ }^{78}$ All these methods have their limitations and give only a partial view of the total innervation.

Recently two highly acidic soluble proteins have been isolated from brain extracts and characterised. ${ }^{9}$ The first, neurone-specific enolase (NSE), is an isoenzyme of the glycolytic enzyme enolase. ${ }^{10}$ Antibodies raised against this enzyme and used as immunochemical reagents show that it is specifically iocalised in neurones ${ }^{11}$ in both the central and the

Address for reprint requests: Dr Julia M Polak, Department of Histochemistry, Royal Postgraduate Medical School, Hammersmith Hospital, London W12 0HS.

Accepted 7 January 1983 peripheral nervous systems ${ }^{12}$ as well as in neuroendocrine cells throughout the body. ${ }^{1314}$ The second protein is $\mathrm{S}-100$ (so named because of its solubility in $100 \%$ ammonium sulphate at neutral $\mathrm{pH}$ ), a calcium-binding protein, ${ }^{15}$ which is found by immunocytochemical methods in glia of the central nervous system ${ }^{16}$ and glial cells of the peripheral ganglia as well as Schwann cells in peripheral nerves. ${ }^{17} 18$ In view of the localisation of NSE and S-100 in neurones and glial cells respectively in other tissues, we have studied the respiratory tract of man and three other mammalian species to see whether its innervation can be delineated by immunostaining with antibodies to these proteins. We have also compared the distribution of NSE and S-100 immunoreactivity with that of acetylcholinesterase-positive nerves, noradrenergic nerves, and peptide-containing nerves in all four species.

\section{Methods}

Tissue

The respiratory tract was obtained from six adults 
(four men and two women aged 18-73 years, mean 60 years) and four children (two boys and two girls, two aged 24 hours, one 6 months, and one 6 years) dying of non-cardiopulmonary causes. Only fresh postmortem material, obtained less than 24 hours after death; was examined. In each case the areas dissected out included the trachea, major bronchi, the inner lung zone containing minor bronchi, the middle lung zone containing medium-sized bronchi, and the outer lung zone including alveoli. In addition, fresh surgical biopsy specimens of nasal mucosa from the inferior turbinate area were taken at operation from eight adult patients (five men and three women aged 18-73 years, mean 39 years) undergoing upper respiratory tract surgery for conditions not related to the nasal mucosa.

Eleven cats (six male and five female, $2 \cdot 6-4 \cdot 2 \mathrm{~kg}$ ), eight Wistar rats (all female, 190-250 g), and six Dunkin Hartley guinea pigs (four male and two female, $350-450 \mathrm{~g}$ ) were studied. The rats and guinea pigs were killed by cervical dislocation and the cats with an intraperitoneal injection of sodium pentobarbitone. In each case the areas examined were similar to the areas of human material examined but the nasal mucosa was also included in the dissection.

Each sample of tissue was fixed and processed for conventional histology, immunocytochemistry, and histochemistry.

Fixation Each piece of fresh tissue, about $1.5 \times$ $0.75 \times 0.5 \mathrm{~cm}$, was divided into three equal parts, each part being fixed by one of three methods. (1) Tissue was fixed in parabenzoquinone solution $(0.4$ $\mathrm{g}$ benzoquinone in $100 \mathrm{ml} 0.01 \mathrm{~mol} / \mathrm{l}$ phosphatebuffered saline (PBS), $\mathrm{pH} 7.4$ ) for $1-1 \frac{1}{2} 2$ hours at $4^{\circ} \mathrm{C} .{ }^{1920}$ After fixation the tissue was washed overnight in buffered sucrose $(70 \mathrm{mg} / \mathrm{ml}$ sucrose, $0 \cdot 1$ $\mathrm{mg} / \mathrm{ml}$ sodium azide in PBS), then snap frozen and sectioned in a cryostat at $-20^{\circ} \mathrm{C}$. (2) Tissue was snap frozen in Arcton (Freon) 12, precooled in liquid nitrogen at $-153^{\circ} \mathrm{C}$, and freeze dried overnight at $-40^{\circ} \mathrm{C}$. The tissue was then fixed in parabenzoquinone vapour, derived from a solution of parabenzoquinone in toluene, for three hours at $60^{\circ} \mathrm{C}$. After this the blocks were vacuum embedded in paraffin wax. (3) Tissue was fixed in either $10 \%$ formalin solution or Bouin's solution ( $75 \mathrm{ml}$ saturated aqueous picric acid, $25 \mathrm{ml}$ commercial formalin, $1 \mathrm{ml}$ acetic acid) for 6-12 hours, after which it was dehydrated through alcohols to xylene and embedded in paraffin wax.

Multiple serial sections were cut from all blocks at a thickness of 3-7 $\mu \mathrm{m}$ for conventional histology (sections being stained with haematoxylin and eosin and examined to ensure that only normal specimens of the respiratory tract were included in the study) and for comparative immunocytochemistry and histochemistry.

Immunocytochemistry The immunocytochemical techniques were indirect immunofluorescence ${ }^{21}$ and the peroxidase antiperoxidase (PAP) procedure..$^{22}$ The antibodies used were raised against the brain proteins NSE and $\mathrm{S}-100$, the peptides vasoactive intestinal polypeptide (VIP) and substance $P$, and the enzyme dopamine- $\beta$-hydroxylase (DBH), which is concerned in catecholamine biosynthesis and is a marker for catecholamine-containing nerves. ${ }^{23}$ In peripheral sympathetic nerves noradrenaline has been found to be the predominant catecholamine component, so throughout this study we refer to DBH-immunoreactive fibres as noradrenergic. Details of the antibodies and their region specificity are given in the table. The antisera to NSE, S-100 and DBH were raised in rabbits. ${ }^{172324}$ Controls included prior absorption of the antibody with its specific antigen (table). The antiserum to VIP (28 amino acids) was completely absorbed by the whole antigen molecule but did not absorb with the synthetic amino acid fragments $1-22$ or $7-28$. This suggests that the VIP antiserum reacts with the whole VIP molecule. The antiserum to substance $P$ was absorbed by its relevant antigen but not by the synthetic amino acid fragment 7-11. Thus the antiserum to substance $P$ (11 amino acids) appears to be directed towards the middle or $N$-terminal portion of the substance $\mathbf{P}$ molecule. Additional immuno-

Characteristics of the antibodies used

\begin{tabular}{|c|c|c|c|c|}
\hline \multirow[t]{2}{*}{ Antigen } & \multirow[t]{2}{*}{ Antisera specificity } & \multicolumn{2}{|l|}{ Dilution } & \multirow{2}{*}{$\begin{array}{l}\text { Antigen concentration needed } \\
\text { to abolish staining fully } \\
\text { (nmol/ml diluted antiserum) }\end{array}$} \\
\hline & & $I F$ & $P A P$ & \\
\hline $\begin{array}{l}\text { Rat NSE } \\
\text { Bovine S-100 } \\
\text { Porcine VIP } \\
\text { Synthetic substance P } \\
\text { Bovine DBH }\end{array}$ & $\begin{array}{l}\text { Not known } \\
\text { Not known } \\
\text { Whole molecule } \\
\text { Mid portion to } N \text {-terminal } \\
\text { Not known }\end{array}$ & $\begin{array}{l}1: 800 \\
1: 800 \\
1: 1000 \\
1: 2000 \\
1: 400\end{array}$ & $\begin{array}{l}1: 4000 \\
1: 4000 \\
1: 20000 \\
1: 16000 \\
1: 4000\end{array}$ & $\begin{array}{c}1 \cdot 0 \\
2 \cdot 5 \\
0 \cdot 1 \\
10 \\
1 \cdot 0\end{array}$ \\
\hline
\end{tabular}

NSE-neurone-specific enolase; VIP-vasoactive intestinal polypeptide; DBH-dopamine- $\beta$-hydroxylase; IF-indirect immunofluorescence; PAP-peroxidase antiperoxidase. 
cytochemical controls included the use of normal rabbit serum $(1: 2000$ dilution $)$ and of the fluorescein-isothiocyanate conjugate or PAP complex alone.

Histochemistry Benzoquinone-fixed cryostat sections, serial to those on which immunostaining was carried out, were cut and allowed to dry. They were then post-fixed in $10 \%$ formalin in PBS for 15 minutes at room temperature and stained for acetylcholinesterase activity according to the method of El-Badawi and Schenk ${ }^{25}$ for four to six hours at $37^{\circ} \mathrm{C}$. All sections from each area of the respiratory tract were viewed with a Reichert-Jung Polyvar microscope equipped with an ultraviolet source and bright-field Nomarski optics.

\section{Results}

\section{NSE IMMUNOSTAINING}

Immunostaining with antibodies to NSE allowed the simultaneous demonstration of a large number of ganglion cells and an extensive network of nerve fibres throughout the respiratory tract of all species examined. In general, the distribution of NSE was realted chiefly to the airways and blood vessels, particularly in the upper respiratory tract, with a gradual decrease towards the lung periphery. Occa- sional NSE-positive endocrine cells were found scattered in the respiratory epithelium of all the adult species, but they were most frequent in the human infant lung.

\section{Ganglion cells}

NSE-immunoreactive ganglion cells were located in groups of two to 20 cells, mainly in the adventitia of the tracheobronchial wall close to the blood vessels. Smaller groups and occasional single cells were seen in the submucosa of the larger airways. In the trachea and major bronchi ganglion cells were most common in the posterior wall outside the trachealis muscle and cartilage ring. At the hilum they became more evenly distributed around the entire adventitia of the bronchus and gradually diminished in number as the bronchioles were reached. The NSEimmunoreactive ganglion cells in the submucosa of the larger airways were in close proximity to the seromucous glands and blood vessels and became less frequent as the airways got smaller. No NSEimmunoreactive ganglion cells were seen in the walls of the pulmonary vessels in any species, but they were often noted in the connective tissue between the bronchi and pulmonary arteries within the lung, chiefly at the hilum. No NSE-positive ganglion cells were observed in the nasal mucosa of any species.

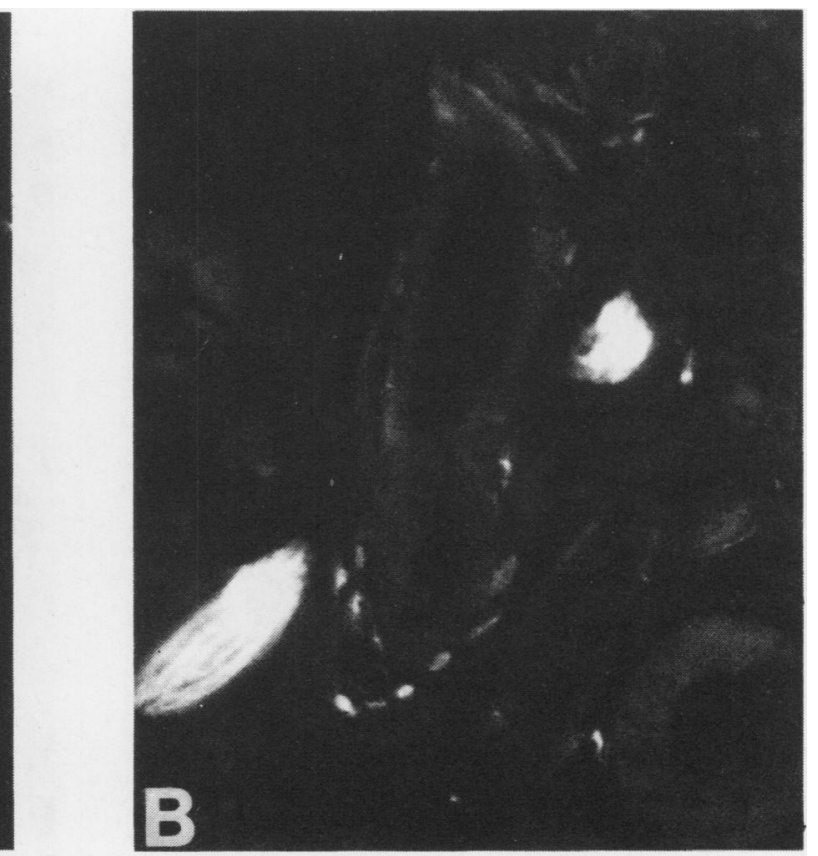

Fig $1 A$ Neurone-specific enolase (NSE)-immunoreactive nerve fibres surrounding the acini of seromucous glands in the human adult nasal mucosa. (Indirect immunofuorescence, $\times 375$.) $B \quad N S E$-immunoreactive nerve fibres in the adventitia of a blood vessel in the human adult nasal mucosa. (Indirect immunofuorescence, $\times 375$.)

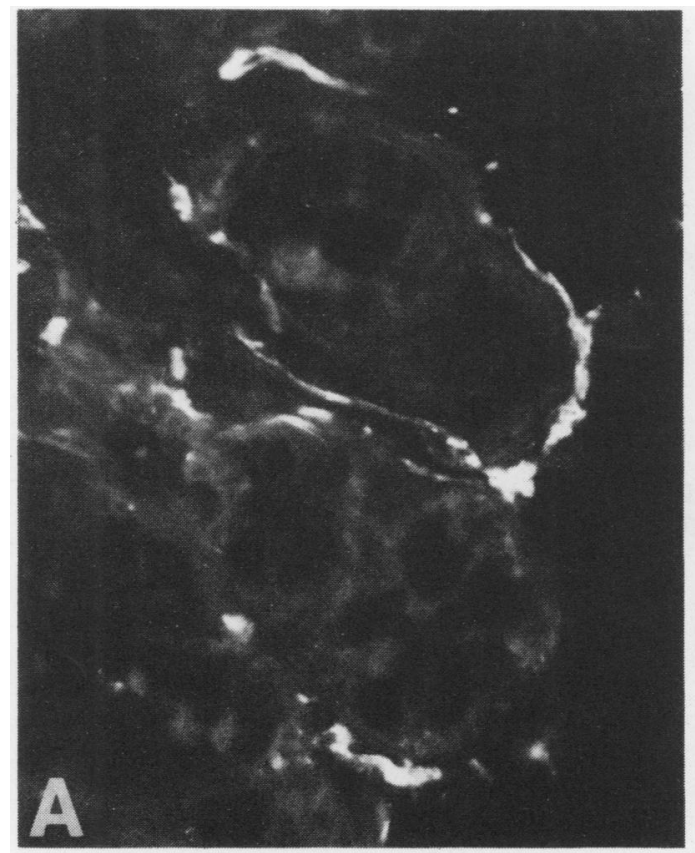




\section{Nerve fibres}

NSE-immunoreactive nerve fibres formed a complex network around the airways and pulmonary blood vessels in all species. As already stated, fibres were most numerous in the upper respiratory tract. In the nasal mucosa NSE-containing nerve fibres were found beneath the epithelium, around seromucous glands, and in the adventitia of blood vessels (fig 1). In the main airways the fibres formed two networks, one outside and the other within the cartilage plates. In the extrachondral network NSEimmunoreactive fibres formed large bundles often in direct continuity with the ganglion cells. In the trachea and major bronchi the fibres were located chiefly in the posterior region, with fewer fibres anteriorly. At the hilum the nerve fibres, like the ganglion cells, had a more even distribution in the adventitia of the bronchial wall. Within the lung NSE-immunoreactive fibres became fewer towards the respiratory portions of the airways, with smaller bundles and single fibres lying in the adventitia of the bronchioles and only an occasional single fibre being identified distal to this. Within the cartilage plates the NSE-immunoreactive fibres formed smaller bundles and surrounded the acini of seromucous glands, the blood vesels, and the smooth muscle. Fibres also extended towards the respiratory epithelium, often lying beneath it, with occasional fine fibres within the epithelium itself. This subchondral network of nerve fibres gradually disappeared as the airways got smaller.

The pulmonary vessels, both arteries and veins, contained NSE-immunoreactive nerve fibres located in the adventitia and extending towards the adventitial-medial junction. These fibres were present down to the level of the small arterioles and venules in the lung periphery in all species.

\section{S-100 IMMUNOREACTIVITY}

Serial sections stained with antibodies to NSE and S-100 showed that in all species S-100 was immunostained only in the supporting glial cells surrounding the NSE-immunoreactive ganglion cells (fig 2), with no immunostaining of the ganglion cell bodies. The S-100-immunoreactive glial cells and their processes formed a dense network around the individual ganglion cells. In all areas where NSEimmunoreactive ganglion cells were found S100 -immunoreactive glial cells surrounded them. In serial sections, throughout the respiratory tract of all species nerve bundles which were found to contain NSE were also S-100 immunoreactive. S-100 immunoreactivity was found in cells with elongated dendritic processes surrounding peripheral nerves. Their morphology and distribution indicated that they were Schwann cells. S-100 immunoreactivity
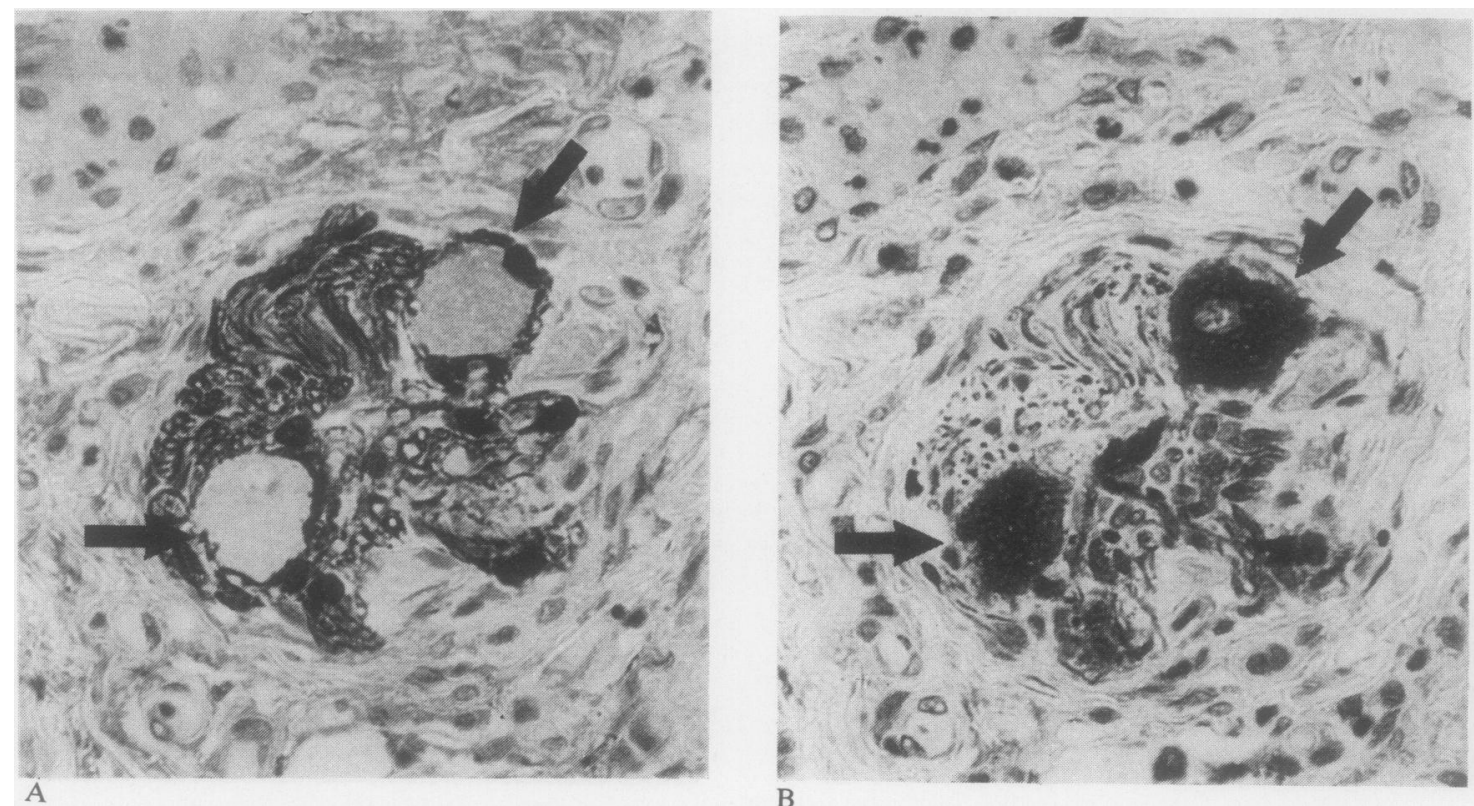

Fig 2 A Two NSE-immunoreactive ganglion cells (arrows) in the adventitia of the human adult major bronchus. (Peroxidase-antiperoxidase method, $\times 500$.) B Section serial to $2 A$, showing S-100-immunoreactive glial cells surrounding the two negative ganglion cell bodies (arrows). (Peroxidase-antiperoxidase method, $\times 500$.) 

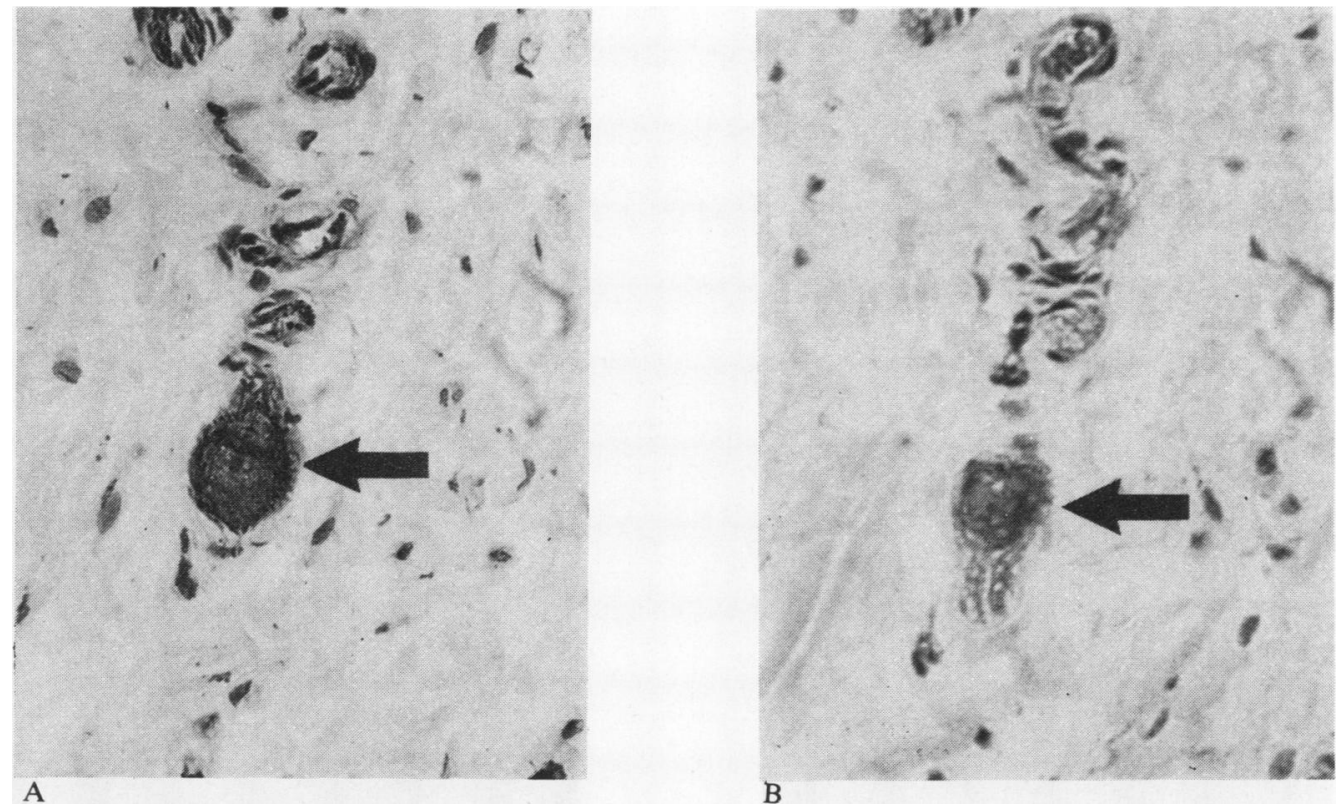

Fig 3 A NSE-immunoreactive ganglion cell (arrow) in the submucosa of the trachea in the human adult. (PAP method $\times 450$.) $B$ Section serial to $3 A$, showing the same ganglion cell containing acetylcholinesterase activity (arrow). (Cholinesterase stain, $\times 450$.)

was also noted in chondrocytes within the cartilage plates, as previously reported..$^{26}$

\section{ACETYLCHOLINESTERASE-CONTAINING NERVE CELLS AND FIBRES}

In serial 6- $\mu \mathrm{m}$ cryostat sections we compared the distributions of NSE-immunoreactive ganglion cells and nerve fibres and those containing acetylcholinesterase activity. The same ganglion cells could be examined with the two stains because most ganglion cells are more than $20 \mu \mathrm{m}$ in diameter, so that several serial sections passed through the same cell, while confident identification of a single nerve fibre in serial sections is not yet possible with current techniques. Thus only the general distribution of nerve fibre bundles could be compared in the serial sections.

In all four species all acetylcholinesterase-positive ganglion cells were also immunoreactive for NSE (fig 3), while acetylcholinesterase-containing nerve fibres had a distribution similar to that of NSEpositive nerve fibres throughout the respiratory tract. In general, NSE-immunoreactive ganglion cells and their fibres were present in larger numbers than those which could be demonstrated by acetylcholinesterase staining.

NORADRENERGIC INNERVATION

With antibodies to DBH noradrenergic nerve fibres were found mainly in the upper respiratory tract, in the airway smooth muscle, and in the adventitia of the tracheobronchial blood vessels. In the lung, fibres were fewer and were related to the adventitia of the bronchial and pulmonary vessels, with few fibres in the airway smooth muscle. Species variation was noted, more fibres being observed in the cat than in the other three species. In serial sections the distribution of noradrenergic nerves was found to be similar to that of NSE-immunoreactive nerves, but NSE-containing nerves were present in much greater numbers. No DBH-positive ganglion cells were identified in any species.

\section{PEPTIDERGIC INNERVATION}

Vasoactive intestinal polypeptide and substance $P$ are the two peptides so far demonstrated by immunocytochemistry in the pulmonary nervous system. ${ }^{27-30}$ VIP immunoreactivity, though present in all species, is found most abundantly in the cat, within both ganglion cells and nerve fibres. In serial sections immunostained with antibodies to NSE and VIP all VIP-immunoreactive ganglion cells were also immunoreactive for NSE (fig 4) but the NSE ganglion cells were more abundant. In addition, all the VIP-immunoreactive ganglion cells contained acetylcholinesterase but there were more acetylcholinesterase-positive ganglion cells than ganglion cells containing VIP. VIP-immunoreactive nerve 

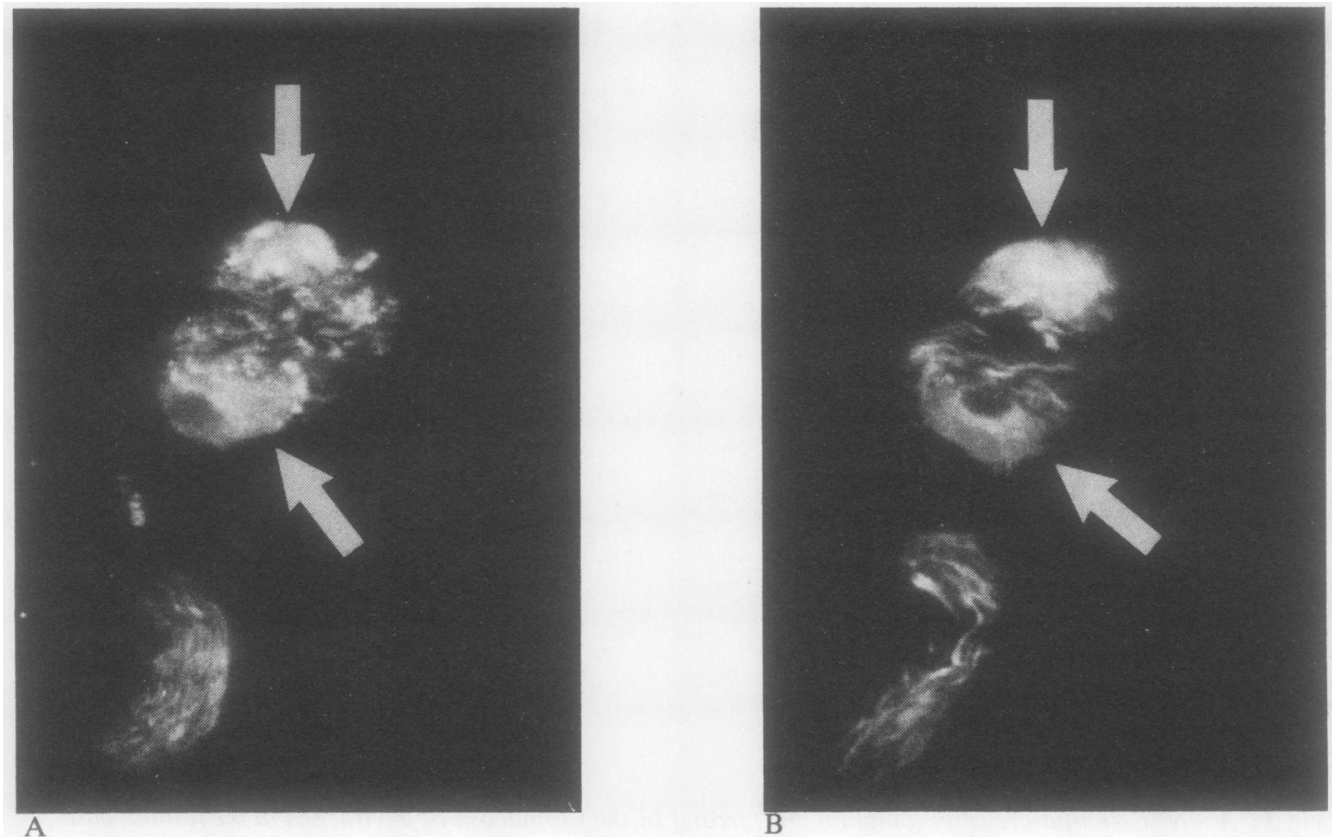

Fig $4 A$ Two NSE-immunoreactive ganglion cells (arrows) in the adventitia of the cat major bronchus. (Indirect immunoftuoresence, $\times 475$.) B Section serial to 4A, showing vasoactive intestinal polypeptide (VIP) immunoreactivity in the same two ganglion cells (arrows). (Indirect immunofuorescence, $\times 475$.)

locations could not be differentiated from NSEimmunoreactive nerves, being chiefly seen around seromucous glands and blood vessels and in the airway smooth muscle.

Substance $P$ immunoreactivity was found within nerve fibres, particularly beneath the respiratory epithelium, in the airway smooth muscle, and around blood vessels. They were seen throughout the respiratory tract of all species but were most prominent in the guinea pig. Serial sections immunostained with antibodies to NSE and substance $P$ showed that wherever nerve fibres containing substance $P$ were located NSE-positive fibres were also stained in adjacent sections.

We noted that the number of NSEimmunoreactive ganglion cells and nerve fibres greatly exceeded those that could be demonstrated by peptide immunocytochemistry.

\section{TISSUE FIXATION}

Both NSE and S-100 immunoreactivity were excellently demonstrated in the formalin and Bouin's fixed paraffin-embedded tissues of all species examined. The tissue fixed in benzoquinone vapour did show denser immunostaining but the distribution of both NSE-containing and S-100-containing nerves did not differ from those seen in the routinely fixed tissues. For the demonstration of acetylcholinesterase-containing, noradrenergic, and peptidergic nerves, however, tissue fixed in benzoquinone solution and made into cryostat blocks gave the best results.

\section{Discussion}

The prominence of the nervous system in the control of normal physiological and pathological processes in the lung has been evident for some years. ${ }^{3132}$ Nevertheless its morphological appearance has received comparatively little attention. This is perhaps due to the lack of specific and reliable markers for nerve cells and their supporting elements. Earlier studies made on the respiratory $\operatorname{tract}^{1-3533}$ used methylene blue and silver impregnation techniques to demonstrate all nervous structures nonspecifically. These techniques, however, are known to give variable results and produce artefacts. ${ }^{23}$ Fisher ${ }^{5}$ stated that both techniques can give variable results depending on the fixation method used and he described nerve ending artefacts, similar to those described by previous authors, which were due to overstaining and trauma.

Later studies using light microscopy have incorporated histochemical methods, mainly acetylcholines- 
terase staining for cholinergic nerves and formaldehyde-induced fluorescence for adrenergic nerves. ${ }^{5834}$ Both of these methods only give a partial view of the total innervation and have certain drawbacks. In the interpretation of acetylcholinesterase staining it should be noted that acetylcholinesterase itself has not been considered a truly specific marker for cholinergic nerves since $1957^{35}$ and recently the enzyme has been shown to hydrolyse substance $P .{ }^{36}$ Diffusion artefacts at nerve endings with cholinesterase staining were shown in extrapulmonary vessels by Fisher. ${ }^{5}$ The formaldehyde-induced fluorescence method for demonstrating aminergic nerves ${ }^{37}$ may give difficulties in interpretation because of the autofluorescence of tissue elastic. Antibodies to DBH will immunostain only catecholaminecontaining nerves and will not demonstrate dopamine-containing structures like the formaldehyde-induced fluorescence method. ${ }^{23}$

In our study, using immunocytochemical techniques with antibodies to NSE and S-100, we have demonstrated very clearly both the neuronal components and the supporting cells of the pulmonary innervation in man and three other mammalian species. NSE has already been shown to be a reliable and specific enzymatic marker for ganglion cells and nerve fibres in many tissues, ${ }^{12} 14$ including the human fetal lung. ${ }^{38}$ Immunostaining with antibodies to S-100 is an excellent means of demonstrating the supporting glial cells of pulmonary ganglia and the Schwann cells of peripheral nerves, both of which have been poorly described in the respiratory tract at the light microscopic level.

An important finding was that the distribution of NSE immunoreactivity was similar to that of acetylcholinesterase-positive nerve cells and fibres, the noradrenergic innervation, and the peptidecontaining nerve cells and fibres, so that NSE appears to be a specific marker for all the components of the lung innervation. In addition, both NSE and S-100 immunoreactivity showed more than had hitherto been seen by either the histochemical methods or peptide immunocytochemistry. The presence of NSE-immunoreactive nerve cells and fibres in larger numbers than had been apparent with the other methods may indicate that there are still other nerve cells and fibres, whose neurotransmitter has not yet been discovered. Another advantage of using these two immunocytochemical markers to delineate the lung innervation is that their antigenicity is preserved after fixation in both formalin and Bouin's solutions. Thus retrospective studies on the lung innervation are possible.

Our results are particularly applicable to studies of lung pathology. The nervous system of the lung plays a major part in the control of airway smooth muscle, ${ }^{31}{ }^{32}$ pulmonary blood flow, ${ }^{39}$ and glandular secretion. ${ }^{40}$ Thus its evaluation in pathological states is essential and immunostaining with antibodies to NSE and S-100 provides a simple histological means for rapid assessment. Separate components of the nervous system can then be examined by the techniques of enzyme histochemistry or peptide immunocytochemistry.

This work was supported by the Medical Research Council and the United States Council for Tobacco Research. MNS has a Wellcome research fellowship.

\section{References}

${ }^{1}$ Larsell G, Dow RS. The innervation of the human lung. Am J Anat 1933;52:125-46.

${ }^{2}$ Gaylor JB. The intrinsic nervous mechanism of the human lung. Brain 1934;57:143-61.

${ }^{3}$ Spencer $H$, Leof $D$. The innervation of the human lung. $J$ Anat (Lond) 1964;98:599-609.

4 Taylor IM, Smith RB. Intrinsic innervation of the human foetal lung between the 35 and $140 \mathrm{~mm}$ crown-rump length stages. Biol Neonate 1971;18:193-202.

${ }^{5}$ Fisher AWF. The intrinsic innervation of the pulmonary vessels. Acta Anat 1965;60:481-96.

${ }^{6}$ El-Bermani AW, Grant M. AChE positive nèrves of the rhesus monkey bronchial tree. Thorax 1975;30:162-70.

${ }^{7}$ Cech S, Dolezel S. Monoaminergic innervation of the pulmonary vessels in various laboratory animals (rat, rabbit, cat). Experientia 1967;23:114-5.

${ }^{8}$ O'Donnell SR, Saar N, Wood LJ. The density of adrenergic nerves at various levels in the guinea pig lung. Clin Exp Pharmacol Physiol 1978;5:325-32.

9 Moore BW. Chemistry and biology of two proteins S-100 and 14-3-2, specific to the nervous system. Int Rev Neurobiol 1972;15:215-25.

${ }^{10}$ Marangos PJ, Zomzely-Neurath C. Determination and characterisation of neuron-specific protein (NSP) associated enolase activity. Biochem Biophys Res Commun 1976;68:1309-16.

${ }^{11}$ Pickel VMD, Reis J, Marangos PJ, Zomzely-Neurath C. Immunocytochemical localization of nervous system specific protein (N.SP-R) in rat brain. Brain Res 1975;105:184-7.

12 Marangos PJ, Schmechel DE. The neurobiology of the brain enolases. In: Youdim MBH, Lovenberg W, Sharman DF, Lagnado JR, eds. Essays in neurochemistry and neuropharmacology. Vol. 4. New York: John Wiley and Sons, 1980:211-47.

${ }^{13}$ Schmechel DE, Marangos PJ, Brightman MW. Neuron specific enolase is a marker for peripheral and central neuroendocrine cells. Nature 1979;276:834-6.

14 Bishop AE, Polak JM, Facer, P, Ferri G-L, Marangos PJ, Pearse AGE. Neuron-specific enolase: a common marker for the endocrine cells and innervation of the gut and pancreas. Gastroenterology 1982;83:902-15.

is Klee CB, Crouch TH, Richman PG. Calmodulin. Annu Rev Biochem 1980;49:489-511.

${ }^{16}$ Zomzely-Neurath CE, Walker WA. Nervous systemspecific proteins 14-3-2 protein, neuron specific enol- 
ase and S-100 protein. In: Bradshaw RA, Schneider DM, eds. Peptides of the nervous system. 2nd ed. New York: Raven Press, 1980:57.

${ }^{17}$ Cocchia D, Michetti F. S-100 antigen in satellite cells of the adrenal medulla and the superior cervical ganglion of the rat: an immunochemical and immunocytochemical study. Cell Tissue Res 1981;215:103-12.

18 Stefansson K, Wollmann RL, Moore BW. Distribution of S-100 protein outside the central nervous system. Brain Res 1982;234:309-17.

19 Pearse AGE, Polak JM. Bifunctional reagents as vapour- and liquid-phase fixatives for immunohistochemistry. Histochem J 1975;7:179-86.

${ }^{20}$ Bishop AE, Polak JM, Bloom SR, Pearse AGE. A new universal technique for the immunocytochemical localization of peptidergic innervation. J Endocrinology 1978(a);77:25-6.

${ }^{21}$ Coons AH, Leduc EH, Connolly JM. Studies on antibody production: $1 \mathrm{~A}$ method for the histochemical demonstration of specific antibody and its application to a study of the hyperimmune rabbit. J Exp Med 1955;102:49-60.

${ }^{22}$ Sternberger LA. Immunocytochemistry. 2nd ed. New York: John Wiley and Sons, 1979:104-69.

${ }^{23}$ Rush RA, Geffen LB. Dopamine $\beta$-hydroxylase in health and disease. $C R C$ Crit Rev Clin Lab Sci 1980;12:241-77.

${ }^{24}$ Marangos PJ, Schmechel D, Param A, et al. Measurement of neuron-specific (NSE) and non-neuronal (NNE) isoenzymes of enolase in rat, monkey and human nervous tissue. J Neurochem 1979;33:319-29.

${ }^{25}$ El-Badawi A, Schenk EA. Histochemical methods for separate, consecutive and simultaneous demonstration of acetylcholinesterase and norepinephrine in cryostat sections. J Histochem Cytochem 1967;15:580-8.

${ }^{26}$ Stefansson K, Wollmann RL, Moore BW, Arnason BGW. S-100 protein in human chondrocytes. Nature 1982;295:63-4.

${ }^{27}$ Uddman R, Alumets J, Densert O, Håkanson R, Sundler F. Occurrence and distribution of VIP nerves in the nasal mucosa and tracheobronchial wall. Acta Otolaryngol (Stockh) 1978;86:443-8.

${ }^{28}$ Dey RD, Shannon WA, Said SI. Localization of VIPimmunoreactive nerves in airways and pulmonary ves- sels of dogs, cats and human subjects. Cell Tissue Res 1981;220:231-8.

29 Wharton J, Polak JM, Bloom SR, Will JA, Pearse AGE. Substance P-like immunoreactive nerves in mammalian lung. Invest Cell Pathol 1979;2:3-10.

${ }^{30}$ Ghatei MA, Sheppard MN, O'Shaughnessy DJ, Adrian TE, McGregor GP, Polak JM, Bloom SR. Regulatory peptides in the mammalian respiratory tract. Endocrinology 1982;ifi:1248-54.

${ }^{31}$ Widdicombe JG, Sterling GM. The autonomic nervous system and breathing. Arch Intern Med 1970;126:311-30.

${ }^{32}$ Richardson JB. The neural control of human tracheobronchial smooth muscle. In: Lichtenstein LM, Austen KF, eds. Astham. Vol 2. New York: Academic Press, 1977:232-50.

${ }^{33}$ Fisher AWF. The intrinsic innervation of the trachea. $J$ Anat (Lond) 1964;98:117-24.

34 El-Bermani AW, McNary WF, Bradley DE. The distribution of acetylcholinesterase and catecholamine containing nerves in the rat lung. Anat $R e c$ 1970;167:205-7.

${ }^{35}$ Pepler WJ, Pearse AGE. The histochemistry of the esterases of rat brain with special reference to those of the hypothalamic nuclei. $J$ Neurochem 1957;1:193 202.

${ }^{36}$ Chubb IW, Hodgson AJ, White GH. Acetylcholinesterase hydrolyses substance P. Neuroscience 1981;5:2065-72.

${ }^{37}$ Falck B, Owman $\mathrm{CH}$. A detailed methodological description of the fluorescence method for cellular demonstration of biogenic monoamine. Acta Univ Lund 1965;11:71-123.

38 Wharton J, Polak JM, Cole GA, Marangos PJ, Pearse AGE. Neuron specific enolase as an immunocytochemical marker for the diffuse neuroendocrine system in human foetal lung. J Histochem Cytochem 1981;29:1359-64.

${ }^{39}$ Evans-Downing S, Lee JC. Nervous control of the pulmonary circulation. Annu Rev Physiol 1980;42:199 210.

${ }^{40}$ Davis B, Chinn R, Graff P, Popovac D, Nadel J. Effects of phenylephrine and superior laryngeal nerve stimulation on submucosal gland secretion in canine trachea in vivo. Clin Res 1979;27:55 (abstract). 